Discourse and Communication for Sustainable Education, vol. 8, no. 2, pp. 17-23, 2017

\title{
Rights-based Approach: The Hub of Sustainable Development
}

\author{
Yesudas Choondassery \\ Berkeley College, the United States of America
}

\begin{abstract}
A rights-based approach to the environmental issues has been gaining momentum since the United Nations' Environmental Agency proposed a new rights-based agenda for sustainable development in the document, Transforming our world: The 2030 Agenda for Sustainable Development (UN, 2015). Our moral responsibility toward the environment is essential to the project of sustainable development. The Kantian ethical tradition lays the foundations of a rights-based approach to human rights and sustainable development. Human rights are essential to the flourishing of all human beings regardless of their nationality or another status. Linking human rights to environmental justice has been an arduous task, but contemporary environmental ethicists argue that giving a human face to the environment that nurtures and sustains us is a precondition for sustainable development. The concept of sustainability addresses the issue of economic growth at present and how this impacts the future generations. This paper examines the rightsbased environmental ethics, which has emerged in the context of a human rights-based approach to human development and forges a link between rights-based ethics and sustainable development that could establish a solid foundation for environmental justice.
\end{abstract}

Keywords: human rights, sustainable development, ecosystems, Kantian ethics, environment.

\section{Introduction}

A leading myth of the human rights-based approach is that it is purely ideological, and its foundations are whimsical. Some critics of human rights assume that human rights are not "real" (MacIntyre, 2007). But human rights-based moral inquiry, analysis and activism have developed from the "real" experience of the dehumanization and violation of the dignity of the human person for centuries. This moral framework has generated a body of knowledge and insights into the agenda of human equality rooted in the dignity and value of the human person. For example, studies in genocide, racism, xenophobia, poverty, etc., are all linked to human rights studies. Since the declaration of the United Nations, The Universal Declaration of Human Rights on December 10, 1948, there has been a proliferation of literature in human rights studies that have established a well-founded framework for the human rights based approach to sustainable 
development. Philosophers, social activists, and political thinkers continue to affirm the value of rights and duties in sustainable development. For a sustainable future of humanity, we must invest in the principle of sustainability, which is an eco-centric worldview that argues that the humans must take an active role in sustainable development because of our moral and legal duties and obligations to this planet and the future generations. The interconnectedness of the ecosystems, and our duties and obligations to a rapidly deteriorating and overburdened planet call for creating a more sustainable future by reevaluating the values of consumerism and materialism that are threats to economic and environmental justice.

The United Nations' Transforming the Word: The 2030 Agenda for Sustainable Development is undeniably human rights-based. The 2030 Agenda mandates everyone "to protect the planet from degradation, including through sustainable consumption and production, sustainably managing its natural resources and taking urgent action on climate change, so that it can support the needs of the present and future generations" (UN, 2015, p. 3). The connection between human rights and sustainable development is a "precondition for sustainable development"(IDRC, 2013, p. 1). Defending the rights of people to have a safe environment in which they can flourish is a precondition for sustainable development (Salite, 2015). The interconnection between the environment and development were first affirmed in the 1972 Stockholm Conference on Environment and Development and continued the discussion in 1992 Rio Earth Submit to address the challenges to global sustainable development ("UN Conference on Environment and Development," 1992). To attain sustainable development, IDRC (2013) points out that "decisions at all levels must consider the three interconnected pillars of sustainable development - socio-cultural, economic and environmental systems" (p. 3). Sustainable development is impossible without considering the role of humans in environmental justice.

\section{The Rights-Based Approach: A Conceptual Framework}

The rights-based approach to sustainable development is a conceptual framework evolved from the moral framework of human rights. This framework is, as stated in IDRC (2013) document, "is a "container" that shapes its content" by introducing the "international human rights standards into discussions, policies, conventions, and processes that address sustainable development" (p. 4). A rights-based ethical approach presupposes that humans are at the center of sustainable development. It doesn't work in the pattern of superior/inferior binary, but rather as co-creators and active agents in the act of creating, nurturing and sustaining the environment with all living organisms. The proponents of sustainable development consistently argued that "It makes perfect sense to link human rights to sustainable development: the right to life cannot be realized without basic rights to safe water, air and land. A human rights approach allows the quality of life of all people to be a central part of decision making." (Adebowale, Church, Kairie, Vasylkivsky, \& Panina, 2001, p. para. 4). They argue that the contemporary approach to sustainable development uses two methods; first, applying the existing human rights methods to advance environmental causes, and secondly, translating grievances into new rights, which are not included in the traditional lists of rights in order to find novel ways to protect the environment and life. For example, the right clean and safe environment or the right to participate in environmental decision-making. 
The concept of human rights is first and foremost a moral ideal with political and legal implications. At the core of this notion stands the belief that "the authority of the community and its institutions and leaders is limited vis-ą-vis the individual" (Amesbury \& Newlands, 2008, p. x). The article 1 of the Universal Declaration of Human Rights makes an a priori claim that "All human beings are born free and equal in dignity and rights. They are endowed with reason and conscience and should act toward one another in a spirit of brotherhood" ("Universal Declaration of Human Rights," 1948, p. 2). This claim is founded on a self-evident truth that each person possesses inalienable rights and has dignity because all human beings share a common essence or human nature.

The contemporary philosophical theories of human rights have foundations in Kantian ethical tradition. Coomans et al. (2010) point out that today human rights researchers and theorists have ignored "the fact that the pursuit of human rights is not a goal in itself, but is merely an instrument designed to help improve respect for human dignity" (p. 182). The human rights are not an end, rather a means to an end or from an Aristotelian perspective human rights can be seen as a means to achieve the goal of happiness in human life.

The critics of human rights question the validity of a metaphysical theory of human rights because of the "intellectual skepticism about its conceptual soundness" and that "they are foundationally dubious and lacking in cogency" (Sen, 2004, p. 315). MacIntyre (2007), for instance, argues that the Universal Declaration of Human Rights is ineffective because such a foundation of human rights does not exist or such moral claims are baseless, and the "belief in them is one with belief in witches and in unicorns" (p. 69). MacIntyre, however, has recently recanted his skepticism of human rights morality because of the possibility of grounding it in the Aristotelian tradition (MacIntyre, 2008; Tasioulas, 2010, p. 649).

Amartya Sen (2004) claims that to construct a theory of human rights, we must ask certain specific questions, which are not elucidated in statements of the Universal Declaration of Human Rights. For example, why human rights are necessary? What kind of duties and obligations do they generate? What kind of actions are required to promote human rights? Are the economic and social rights (second generation rights) reasonable? And how does a theory of human rights defend its universality in a diverse world where cultural relativism is perverse? (p. 315-319). Sen (2004) believes that human rights are "primarily ethical demands" and even though they can lead to legislation, having legal validity is not a "constitutive characteristic of human rights." They can be rather promoted through other means such as "public discussion, appraisal, and advocacy." The freedoms that they advance must satisfy the conditions of "special importance" and "social influenceability" (p. 353-354). John O’Manique (1990) argues that the universality of human rights relates to "the idea of survivability in unobstructed discussion - open to participation by persons across national boundaries" (p. 468). O'Manique (1990) claims that human rights must have a foundation in the question of human "survival," which is inherent in or existential to human life (p. 469). This concept serves better rather than the controversial idea of human dignity as a foundation for human rights, according to some critics.

Marie-Benedicte Dembour (2010) locates the human rights approaches within four schools of thought, the Natural school, the Deliberative school, the Protest school, and the Discourse school. The Natural school follows the tradition of natural law, universal reason, and argues that the human rights are entitlements, naturally given to us because 
of our human nature. The Deliberative school maintains that they are agreed upon by people as to how a society should be governed using human reason. The Protest school considers human rights as something that people fight for which come from the tradition of social struggle and the quest for social justice. The Discourse school simply considers it as something "talked about" and it has become a powerful language to express political claims. However, the Discourse school proponents do "fear the imperialism of human rights imposition and stress the limitations of an ethic based on individual human rights" (Dembour, 2010, p. 4). These four schools of thoughts help us understand the contemporary human rights-based approaches.

One of the compelling arguments for the ethical foundation for human rights-based approaches come from our moral nature that values the inherent dignity of the person and the moral demand of promoting and protecting it. Jack Donnelly (2003), a leading proponent of this view follows a 'constructivist' theoretical approach and argues that:

The source of human rights is man's [sic] moral nature, which is only loosely linked to the "buman nature" defined by scientifically ascertained needs. The "buman nature" that grounds human rights is a prescriptive moral account of human possibility. The scientist's human nature says that beyond this we cannot go. The moral nature that grounds human rights says that beneath this we must not permit ourselves to fall (p. 14).

Human rights, continues Donnelly, are required for a life of dignity because they set limits and requirements of social action and when human rights claims bring about a legal and political practice they "create the type of person posited in that moral vision" (p. 15). Human rights-based approach presents a strategy for the realization of a specific mode of environmental justice using a conceptual framework rooted in the moral nature of the environment in which humans and all living beings find a sustainable natural habitat.

\section{Sustainable Development in the Context of Human Rights}

Environmental justice is a pre-requisite for sustainable development. The idea of sustainable development was born in United Nations Stockholm Conference on Environment and Development in 1972 ("Report of the United Nations Conference on Human Environment," 1973). The advocates of rights-based approach suggest the following three principal areas that will serve the foundation for "increased sustainability" (IDRC, 2013, p. 3):

1. The right to a clean and safe environment

2. Access to information and public participation in decision-making

3. The right to promote and defend the protection of the environment and human rights.

The right to a healthy environment is a basic human right. Integrating this fundamental right to the policies and the decision-making process contribute to the promotion and protection of the environment. Contemporary environmental justice philosophy and practice focus on "the effects that an unhealthy environment can have on the health of individual and communities" (IDRC, 2013, p. 4).

One of the fundamental rights of human beings is the right to life. The realization of this right requires access to clean water, air, and land so that everyone can maintain 
the quality of life. Therefore, human rights approach to the environment becomes a crucial element of developing policies that protect the right to life of all. The decisionmaking process of the governments and international agencies like the United Nations have a profound impact on the life and well-being of people around the globe.

The critics of rights-based ethics may argue that applying human rights to environmental ethics could lead to a rugged anthropocentric worldview. Nevertheless, to achieve the goal of sustainable development, several ecological thinkers argue that we must reevaluate a strictly anthropocentric worldview from the perspective of an ecocentric or biocentric worldview, which holds that all life forms, not just humans, have intrinsic worth or value (Leopold, 1949; MacKinnon \& Fiala, 2015; Rolston III, 1988). The concept of sustainable development recognizes the rights of both the humans and the environment. The decision-making process of sustainable development must consider the notion of social equity. Usually, the burden of economic growth falls on the environment and the disadvantaged members of the society.

To realize the ideal of sustainable development the economic and environmental costs and benefits of development have to be equitably distributed by "paying attention to disadvantaged groups in society, including, women, youth and children, the elderly, indigenous groups, and ethnic minorities" (IDRC, 2013, p. 4). It also includes the intrinsic value of the ecosystem and all life forms. Aldo Leopold in his famous essay, "The Land Ethic" suggests that one must think about the land as "a fountain of energy flowing through a circuit of soils, plants, and animals” (Leopold, 1949, p. 262). The intrinsic value of the ecosystem is a non-negotiable principle of sustainable development.

Naturally, the question is, what would this innovative approach to sustainability, the rights-based approach, do to ensure sustainable development? Iliško (2017) suggests that "both restorative and transformative learning illustrate an efficient educational process for sustainability" (p. 15). Education for sustainability begins from both the academia and the grass root levels of the society. For example, including the rightsbased approach to sustainable development as a part of the academic curriculum, developing and implementing programs in micro level community organizations, etc., will educate the public and decision-makers to consider environmental issues and economic development in the broader context of human rights and environmental justice.

Sustainable development is the foundation for environmental justice. Environmental justice is not a novel idea. The Environmental Protection Agency of the United States (EPA) defines it as "the fair treatment and meaningful involvement of all people regardless of race, color, national origin, or income, with respect to the development, implementation, and enforcement of environmental laws regulations, and policies" (EPA, para 1). Although the EPA definition does not directly imply a right-based conceptual framework, it can be drawn from the perspective of social justice and equity, because it is "the poor and disenfranchised who end up suffering most from environmental degradation" (MacKinnon \& Fiala, 2015, p. 239). Researchers have found that the poor in both the developed and emerging nations suffer from environmental disasters or chronic diseases resulting from environmental pollution. MacKinnon and Fiala (2015) argue that a verity of issues that comes under the "rubric of environmental justice," which is predominantly anthropocentric. But a "larger concern for the value of ecosystems" promotes quality of life for all organisms in the context of sustainable development and environmental justice (p. 240-241). 
Traditionally, it was a challenging task to forge a link between human rights and environmental justice because the advocates of the two issues often treat them as two independent issues rather than an interconnected issue like the two sides of a coin. The new rights-based approach considers environmental justice as the "idea that neither environmental amenities nor the effect of severe degradation are distributed uniformly, with negative consequences most often borne by oppressed and marginalized groups in society" (IDRC, 2013, p. 8). Unsustainable economic growth compromises the rights of the people who unjustly suffer the consequences of environmental degradation and exploitation. Sustainable development in the context of human rights gives priority to the right to have a healthy environment that promotes the flourishing of all.

\section{Conclusions}

As mentioned in the above discussion, a rights-based approach to sustainable development is a rapidly developing approach to environmental ethics. There are many approaches to environmental justice, such as anthropocentric worldview, biocentric or ecocentric worldview, deep ecology, etc. While these methods are still discussed and debated, an innovative approach has evolved in recent years focusing on rights-based ethics. Scholars argue that although we have passed over thirty years since the development of the idea of sustainable development, the socio-cultural, economic and environmental issues have not changed much. People continue to live in poverty, the gap between the rich and the emerging nations and people are widening, ecological degradation and exploitation continue to exist. In this context, environmental activists and scholars have developed a new strategy or approach, giving a human face to the environment and considering the ecological issues as direct violations of the right to life.

According to this view, all forms of environmental exploitation must be a violation of the rights of human beings to have a safe and secure environment in which all living can flourish and thrive. Environmental rights are a prime requisite for all to function well. By establishing a conceptual link between human rights and environmental justice, the moral framework of environmental justice becomes not only a human-centered ethics but also an eco-centered ethics. All living organisms become the center of sustainable development. Sustainable development is not possible without considering the impact of environmental degradation specifically on marginalized and oppressed groups. The aggrieved groups must become active participants in the decision-making process and create policies that promote environmental justice and protect the right of all to have a healthy environment. The voice of the people becomes a substantial part of the integration of human rights and sustainable development.

\section{References}

Adebowale, M., Church, C., Kairie, B. N., Vasylkivsky, B., \& Panina, Y. (2001). Environment and human rights: A new approach to sustainable development. Retrieved from https://www.iatp.org/files/Environment_and_Human_Rights_A_ New_Approach_to.htm

Amesbury, R., \& Newlands, G. M. (2008). Faith and human rights: Christianity and the global struggle for human dignity. Minneapolis: Fortress Press. 
Coomans, F., Grünfeld, F., \& Kamminga, M. T. (2010). Methods of human rights research: A primer. Human Rights Quarterly, 32(1), 179-186.

Dembour, M.B. (2010). What are human rights? Four schools of thought. Human Rights Quarterly, 32(1), 1-20.

Donnelly, J. (2003). Universal human rights in theory \& practice. (2nd ed.). Ithaca: Cornell University Press.

EPA. (August 8, 2017). Environmental Justice. Retrieved from https://www.epa.gov/ environmentaljustice

IDRC. (2013). The human rights approach to sustainable development: Environmental rights, public participation and human security. Insights Series 2. Retrieved from http://unac.org/wp-content/uploads/2013/07/HRandSD-EN-PDF.pdf

Iliško, D. (2007). Teachers as agents of societal change. Journal of Teacher Education for Sustainability, 7, 14-26.

Leopold, A. (1949). The land ethic. In Sand county Almanac. New York: Oxford University Press.

MacIntyre, A. (2007). After virtue: a study in moral thoery (3rd revised ed.). Notre Dame, Indiana: The University of Notre Dame Press.

MacIntyre, A. (2008). What more needs to be said? A beginning, although only a beginning, at saying it. Analyse und Kritik, 30, 261-281.

MacKinnon, B., \& Fiala, A. (2015). Ethics: Theory and contemporary issues. Stamford, CT: Cengage Learning.

O’Manique, J. (1990). Universal and inalienable human rights: A search for foundation. Human Rights Quarterly, 12, 465-485.

Report of the United Nations Conference on Human Environment. (1973). Retrieved from http://www.un-documents.net/aconf48-14r1.pdf

Rolston III, H. (1988). Environmental ethics: Duties to and values in the natural world. Philadelphia: Temple University Press.

Salite, I. (2015). Searching for sustainability in teacher education and educational research: Experiences from the Baltic and Black Sea Circle Consortium for educational research. Discourse and Communication for Sustainable Education, 6, 21-29.

Sen, A. (2004). Elements of a theory of human rights. Philosophy \& Public Affairs, 32(4), 315-356.

Tasioulas, J. (2010). Taking rights out of human rights. Ethics, 120, 647-678.

UN. (2015). Transforming our world: the 2030 Agenda for Sustainable Development. Retrieved from https://sustainabledevelopment.un.org/post2015/transforming ourworld

UN Conference on Environment and Development. (1992). Retrieved from http:/www. un.org/geninfo/bp/enviro.html

Universal Declaration of Human Rights. (1948). Retrieved from http://www.jus.uio.no/ lm/un.universal.declaration.of.human.rights.1948/portrait.a4.pdf

Correspondence concerning this article should be addressed to Yesudas Choondassery, PhD., Faculty, School of Liberal Arts, Berkeley College, New Jersey, U.S.A. Email: ydc@berkeleycollege.edu 